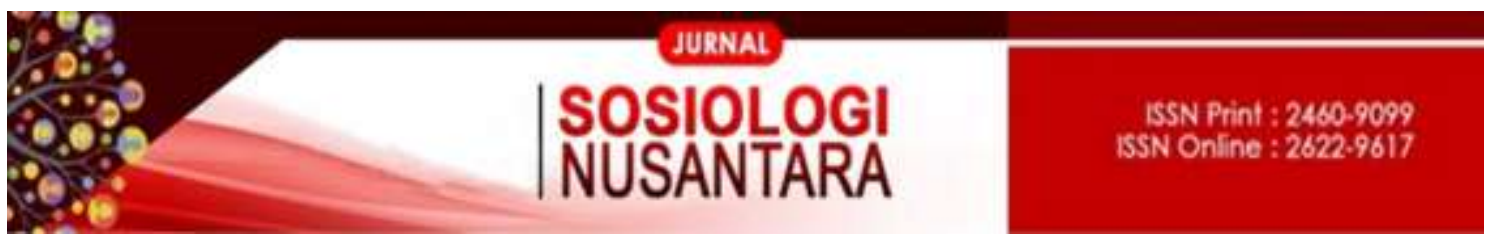

DOI ://doi.org/10.33369/jsn.5.2.140-156

\title{
PENGARUH MOTIVASI DAN PEMBERIAN BEASISWA TERHADAP KEPUTUSAN PEGAWAI MELANJUTKAN PENDIDIKAN KE PERGURUAN TINGGI
}

\section{THE EFFECT OF SELF MOTIVATION AND GRANTING SCHOLARSHIP ON EMPLOYEE DECISION MAKING TO CONTINUE HIGHER EDUCATION AT INDONESIAN RAILWAYS COMPANY REGIONAL DIVISION III PALEMBANG}

\author{
Adetia Wulindari ${ }^{1}$, Yoyok Hendarso ${ }^{2}$, Yunindyawati $^{3}$ \\ adetiawulindari@gmail.com \\ 123Fakultas Ilmu Sosial dan Ilmu Politik, Universitas Sriwijaya
}

\begin{abstract}
Abstrak
Penelitian ini dilakukan di PT Kereta Api Indonesia Divisi Regional III Palembang sebagai salah satu perusahaan yang bergerak di bidang transportasi darat. Tujuan dari penelitian ini adalah : (1) untuk menganalisis pengaruh motivasi diri terhadap pengambilan keputusan pegawai dalam melanjutkan pendidikan ke perguruan tinggi, (2) untuk menganalisis pengaruh pemberian beasiswa terhadap pengambilan keputusan pegawai dalam melanjutkan pendidikan ke perguruan tinggi, (3) untuk menganalisis pengaruh motivasi diri dan pemberian beasiswa terhadap pengambilan keputusan pegawai dalam melanjutkan pendidikan ke perguruan tinggi. Metode yang digunakan dalam penelitian ini adalah kuantitatif. Analisis data dilakukan dengan pengujian hipotesis dengan analisis regresi berganda yaitu uji t dan uji f untuk melihat besarnya pengaruh variabel $X_{1}$ dan $X_{2}$ terhadap variabel Y baik secara parsial maupun secara simultan. Responden dalam penelitian ini terdiri atas 100 orang pegawai yang sedang melanjutkan dan telah selesai melanjutkan pendidikan ke perguruan tinggi. Hasil penelitian yang diperoleh adalah : (1) variabel motivasi diri berpengaruh terhadap pengambilan keputusan pegawai dalam melanjutkan pendidikan ke perguruan tinggi, hal ini ditunjukkan dengan nilai signifikansi sebesar $0.000<\alpha(0,05)$ dan memberikan pengaruh sebesar $32 \%$ terhadap variabel $\mathrm{Y}$, (2) variabel pemberian beasiswa berpengaruh terhadap variabel pengambilan keputusan pegawai dalam melanjutkan pendidikan ke perguruan tinggi, hal ini ditunjukkan dengan nilai signifikansi sebesar $0,025<\alpha(0,05)$ dan memberikan pengaruh sebesar 10,2\% terhadap variabel Y, (3) variabel $X_{1}$ dan $X_{2}$ berpengaruh terhadap variabel $\mathrm{Y}$, hasil ini ditunjukkan dengan signifikansi sebesar $0.000<\alpha(0,05)$ dan memberikan pengaruh sebesar $42.2 \%$ terhadap variabel Y.
\end{abstract}


Kata Kunci: Motivasi Diri, Pemberian Beasiswa, Pengambilan Keputusan Pegawai

\begin{abstract}
This study was conducted at Indonesian Railways Company Regional Division III Palembang as one of the companies engaged in land transportation. The objectives of this study are: (1) to analyze the effect of self motivation on employee decision making to continue higher education, (2) to analyze the effect of granting scholarship on employee decision making to continue higher education, (3) to analyze the effect of self motivation and giving scholarship on employee decision making to continue higher education. The method used in this study is quantitative. The data analysis is conducted by testing the hypothesis in multiple regression analysis, namely the t test and f test to analyze the effect of $X 1$ and $X 2$ variables on $Y$ variable both partially and simultaneously. The respondents of this study consist of 100 employees who have been continuing higher education and who have finished higher education. The study results obtained are: (1) the self motivation variable affects employee decision making to continue higher education, this is indicated by a significance value of $0.000<\alpha(0.05)$ and gives an effect of $32 \%$ on $Y$ variable, (2) the granting scholarship variable affects the employee decision making to continue higher education variable, this is indicated by a significance value of $0.025<\alpha(0.05)$ and gives an effect of $10.2 \%$ on $Y$ variable, (3) $X 1$ and $X 2$ variables affect $Y$ variable, this result is indicated by a significance of 0.000 $<\alpha(0.05)$ and gives an effect of $42.2 \%$ on Y variable.
\end{abstract}

Keywords: Self Motivation, Granting Scholarship, Employee Decision Making

\title{
PENDAHULUAN
}

Pendidikan merupakan bagian penting dalam kehidupan karena pendidikan berfungsi mengembangkan kemampuan dan membentuk watak seseorang. Setiap individu harus mengembangkan potensi-potensi yang dimilikinya. Pendidikan juga berfungsi untuk membentuk watak, sikap dan karakter setiap individu agar bisa menyesuaikan dirinya pada lingkungan masyarakat yang bernilai positif dan tidak menyimpang dengan keadaan. Oleh karena itu untuk mengembangkan kemampuan dan membentuk watak diperlukan proses pembelajaran di dalamnya yang didapatkan di lingkungan sekolah. Undang-Undang Sisdiknas No 20 Tahun 2003 Bab 1 dalam Wiyani (2013)

"Pendidikan adalah usaha sadar dan terencana untuk mewujudkan suasana belajar dan proses pembelajaran agar peserta didik secara aktif mengembangkan potensi dirinya untuk memiliki kekuatan spritual keagamaan, pengendalian diri, kepribadian, kecerdasan, akhlak mulia, serta keterampilan yang diperlukan bagi dirinya, masyarakat, bangsa dan negara." 
Berdasarkan rumusan di atas dapat disimpulkan bahwa pendidikan merupakan modal yang sangat penting dalam menjalani kehidupan bermasyarakat, karena didalam pendidikan para peserta didik dapat memperoleh banyak pengetahuan seperti pengetahuan tentang moral, agama, keterampilan, kedisiplinan dan masih banyak lagi yang lainnya. Menurut Idi (2011) :

"Pendidikan adalah suatu kegiatan yang dilakukan secara sengaja dan terencana yang dilaksanakan orang dewasa yang memiliki ilmu dari keterampilan guna memberikan kompetensi kepada anak didik sehingga mereka memiliki pengetahuan, keterampilan, dan nilai-nilai dasar yang refleksi berpikir dan bertindak demi terciptanya sumber daya manusia yang diinginkan, sebagai al-insan-alkamil."

Dalam menjalani pendidikan seseorang akan melewati jenjang pendidikan sesuai dengan ketentuan yang sudah diatur di dalam UU pendidikan di Indonesia. Jenjang pendidikan dimulai dari sekolah dasar, sekolah menengah pertama hingga sekolah menengah atas. Jenjang pendidikan dalam hal ini adalah tahapan pendidikan yang ditetapkan berdasarkan tingkat perkembangan peserta didik, tujuan yang akan dicapai, dan kemampuan yang dikembangkan. (UU No. 20 Tahun 2003 Bab I, Pasal 1 Ayat 8).

Jenjang pendidikan menengah yang sudah mulai melatih keterampilan peserta didiknya adalah Sekolah Menengah Kejuruan (SMK). Di SMK ini peserta didik sudah dilatih sesuai dengan bidang yang sudah mereka pilih untuk dipelajari hingga mereka menyelesaikan studi agar kelak keterampilan yang mereka dapatkan bisa dipergunakan di dunia kerja, sedangkan pada Sekolah Menengah Atas peserta didik lebih diarahkan untuk memilih jurusan IPA atau IPS agar mereka bisa memahami lebih dalam mengenai jurusan yang sudah mereka pilih dan biasanya akan disesuaikan dengan tingkat kemampuan mereka masing-masing. Hal diatas sejalan dengan pendapat Martono (2011) :

"Institusi pendidikan bertujuan untuk menyiapkan individu agar dapat berperan dalam proses industri. Pendidikan pada masa sekarang masih menjalankan peran yang sama, menyiapkan individu memasuki dunia industri dengan berbekal keahlian yang telah dipelajari di sekolah. Pendidikan dalam hal ini berposisi sebagai objek dalam proses perubahan sosial, pendidikan diposisikan sebagai institusi yang harus selalu mengikuti perkembangan dunia industri. Apa yang dipelajari di sekolah harus sesuai dengan apa yang dibutuhkan dunia industri (dunia kerja) karena memang itulah tugas dan peran institusi dalam masyarakat modern." 
Parsons (dalam Harolombos dan holborn, 2004) melihat bahwa sistem pendidikan juga digunakan sebagai mekanisme penting unuk menyeleksi individu bagi perannya dimasa depan. Dunia pendidikan dan pekerjaan jika dikaitkan berdasarkan pendapat di atas bahwa pada saat ini setiap perusahaan dalam melakukan rekruitmen pegawai baru maka perusahaan akan memberikan syarat/kualifikasi dalam hal jenjang pendidikan sesuai dengan bidang pekerjaan yang dibutuhkan di perusahaan tersebut. Oleh karena itu masing-masing individu seharusnya menempuh pendidikan yang lebih baik agar bisa memenuhi kualfikasi yang diajukan oleh perusahaan dan mendapatkan keterampilan yang lebih khusus lagi. Tingkat pendidikan seseorang tentu akan berpengaruh terhadap pekerjaan yang akan individu dapatkan karena dunia industri juga akan memberikan kualifikasi atau syarat pendidikan sesuai dengan bidang pekerjaan yang dibutuhkan agar pencari kerja dapat mengikuti tes atau tahapan seleksi dalam mencari pekerjaan.

Kualifikasi pendidikan seseorang tidak hanya menunjukkan bahwa orang tersebut memiliki kemampuan, bakat dan sikap tertentu namun juga dapat membentuk sikap, motivasi dan karakter kepribadian lainnya. Hal ini tentu akan membuat sumber daya manusia di dalam sebuah perusahaan semakin lebih baik kedepannya dan membuat para pekerja atau pegawai memiliki motivasi dan kesadaran bahwa mereka harus menjadi pegawai atau pekerja yang semakin kedepan semakin bisa memberikan kontribusi besar untuk perusahaan tempat mereka bekerja sekaligus mendukung pengembangan SDM yang bermutu tinggi, yang tidak hanya tercermin dari ijazah yang dimiliki namun juga dari apa yang dipahami, diketahui dan bisa diperbuat untuk kemajuan perusahaan.

Dalam melanjutkan dan menjalani pendidikan ke jenjang perguruan tinggi terutama untuk individu yang sudah menjadi pegawai dalam perusahaan. Hal ini harus didasari terlebih dahulu dengan motivasi diri yang timbul dan alasan mengapa individu tersebut ingin melanjutkan pendidikan saat dia sudah bekerja selain ingin menjadi sumber daya manusia yang lebih bermutu yang bisa memberikan kontribusi yang lebih baik lagi bagi perusahaannya. Motivasi diri yang timbul dalam diri seseorang untuk melanjutkan pendidikan tentu saja dipengaruhi dari beberapa faktor yang timbul baik dari dalam diri individu tersebut (motivasi intrinsik) ataupun faktor dari luar individu tersebut (motivasi ekstrinsik).

Salah satu perusahaan BUMN yang ada di Indonesia dan merupakan perusahaan besar dalam bidang angkutan darat yaitu jasa angkutan kereta api (PT Kereta Api 
Indonesia ), dalam perusahaan yang besar tentu akan memiliki ribuan pegawai yang sudah memenuhi kualifikasi atau syarat yang sudah ditentukan oleh perusahaan pada saat proses rekruitmen untuk bisa bekerja di perusahaan tersebut. Kualifikasi tersebut salah satunya adalah tingkat pendidikan yang dimiliki oleh calon pegawai PT Kereta Api Indonesia sebelum diterima menjadi pegawai tetap perusahaan. Pada saat diterima ada beberapa pegawai yang sudah menyelesaikan pendidikan di perguruan tinggi namun ada juga yang masih berstatus tamatan Sekolah Menengah Atas sesuai dengan kualifikasi yang diajukan oleh perusahaan.

Tingkat pendidikan yang sering diajukan oleh PT Kereta Api Indonesia pada saat penerimaan pegawai baru adalah pada jenjang Sekolah Menengah Atas jadi pada saat ditetapkan sebagai pegawai mereka hanya berpendidikan SMA. Pada saat sudah menjalani pekerjaan maka tentunya dari beberapa pegawai ada keinginan untuk melanjutkan pendidikan ke jenjang pendidikan tinggi, baik diperguruan tinggi negeri atau swasta. Hal itu dipengaruhi oleh motivasi diri dan peran perusahaan dalam mendukung pegawai untuk melanjutkan pendidikan. Dalam penelitian ini didapatkan data bahwa jumlah pegawai yang ada di PT Kereta Api Indonesia Divisi Regional III, Palembang berjumlah 170 pegawai. Dari 170 pegawai terdapat 48 pegawai yang sedang melanjutkan pendidikan dan 42 pegawai sudah menyelesaikan pendidikan. Dari jumlah tersebut peneliti ingin melihat pengaruh motivasi dan pemberian beasiswa oleh perusahaan terhadap keputusan pegawai dalam melanjutkan pendidikan.

\section{METODE PENELITIAN}

Penelitian ini dilakukan di PT Kereta Api Indonesia Persero Divisi Regional III Palembang. Metode penelitian yang digunakan dalam penelitian ini adalah metode penelitian kuantitatif, menggunakan analisis statistik dengan bantuan program SPSS 23 . Populasi dalam penelitian ini berjumlah 170 pegawai. Sampel yang dipilih dengan menggunakan teknik Frankle dan Wallen yang menyebutkan bahwa besar sampel minimum untuk penelitian deskriptif adalah 100. Variabel dalam penelitian ini terdiri atas dua variabel independen (motivasi dan pemberian beasiswa) dan satu variabel dependen (pengambilan keputusan pegawai). Teknik pengumpulan data yang digunakan adalah kuesioner dan dokumentasi. 
Tabel 1.1 Definisi Operasional Variabel

\begin{tabular}{|c|c|c|c|}
\hline \multirow{2}{*}{ Mariabel } & \multirow{2}{*}{$\begin{array}{l}\text { Dimensi } \\
\text { Motivasi } \\
\text { instrinsik }\end{array}$} & Indikator & \multirow{2}{*}{$\begin{array}{l}\text { Item } \\
1.2,3 \\
4,5,8 \\
6,7,9,10\end{array}$} \\
\hline & & $\begin{array}{l}\text { a) Adanya hasrat dan keinginan } \\
\text { berhasil } \\
\text { b) Adanya dorongan dan } \\
\text { kebutuhan dalam belajar } \\
\text { c) Adanya harapan dan cita-cita } \\
\text { masa depan. }\end{array}$ & \\
\hline & $\begin{array}{l}\text { Motivasi } \\
\text { ekstrinsik }\end{array}$ & $\begin{array}{l}\text { a) Adanya penghargaan dalam } \\
\text { belajar } \\
\text { b) Adanya kegiatan menarik } \\
\text { dalam belajar } \\
\text { c) Adanya lingkungan belajar } \\
\text { yang kondusif sehingga } \\
\text { memungkinkan siswa bisa } \\
\text { belajar dengan baik. }\end{array}$ & $\begin{array}{l}11,12,13,14 \\
15 \\
16,17\end{array}$ \\
\hline \multicolumn{4}{|l|}{$\begin{array}{l}\text { Sumber: Uno } \\
(2011)\end{array}$} \\
\hline Variabel & Dimensi & Indikator & Item \\
\hline $\begin{array}{l}\text { Pemberian } \\
\text { Beasiswa }\left(X_{2}\right)\end{array}$ & & $\begin{array}{l}\text { a) Aspek ekonomi } \\
\text { b) Aspek akademik } \\
\text { c) Aspek karakter }\end{array}$ & $\begin{array}{l}1,2,3 \\
4,5,8 \\
6,7,9,10,11\end{array}$ \\
\hline \multicolumn{4}{|l|}{$\begin{array}{l}\text { Sumber;Ichsan } \\
(2013)\end{array}$} \\
\hline Variabel & Dimensi & Indikator & Item \\
\hline $\begin{array}{l}\text { Pengambilan } \\
\text { keputusan }\end{array}$ & & $\begin{array}{l}\text { a) Tujuan } \\
\text { b) Identifikasi alternatif } \\
\text { c) Faktor yang tidak } \\
\text { dapat diketahui } \\
\text { sebelumnya } \\
\text { d) Dibutuhkan sarana } \\
\text { untuk hasil yang } \\
\text { dicapai }\end{array}$ & $\begin{array}{l}1,2,3,4 \\
4,5,8 \\
6.7 .9 .10 \\
11,12,13,14\end{array}$ \\
\hline $\begin{array}{l}\text { Sumber: } \\
\text { syamsi (2000) }\end{array}$ & & & \\
\hline
\end{tabular}

Data primer yang dikumpulkan dalam penelitian ini adalah data untuk mengetahui serta menganalisis pengaruh motivasi diri dan pemberian beasiswa terhadap pengambilan keputusan pegawai untuk melanjutkan pendidikan ke perguruan tinggi di PT KAI Persero Divisi regional III Palembang. Data primer ini diperoleh secara langsung melalui penyebaran kuesioner dan dokumentasi. Data sekunder yang ada dalam penelitian ini diperoleh melalui buku, internet (web), penelitian terdahulu (jurnal penelitian yang terkait) dan literatur lainnya yang berkaitan dengan penelitian ini.Data statistik dihitung dengan bantuan program spss, sebelum dilakukan pengujian hipotesis baik secara parsial maupun simultan terlebih dahulu dilakukan uji asumsi klasik sebagai uji prasyarat. Uji asumsi klasik dalam penelitian ini adalah uji normalitas, uji multikolinearitas dan uji heteroskedastisitas dan setelah itu dilakukan uji $\mathrm{F}$ dan uji t.

\section{Uji Normalitas Data}

Data yang telah dianalisis kemudian dilakukan pengujian normalitas data. Menurut Ghozali (2013) uji normalitas bertujuan untuk menguji apakah dalam model regresi variabel pengganggu atau residual memiliki distribusi normal. Pengujian ini disebut uji normalitas ini sudah dijelaskan yaitu dilakukan untuk mengetahui normal atau tidaknya distribusi data. Uji normalitas juga perlu dilakukan untuk mengetahui 
apakah data yang dianalisis normal atau tidak, karena uji statistik parameter $\mathrm{t}$ atau uji-t dapat digunakan apabila data terdistribusi secara normal. Pada penelitian ini untuk melihat kenormalan data, peneliti menggunakan bantuan program SPSS. Uji normalitas ini dilakukan dengan menggunakan uji kolmogrov smirnov. Menurut Ghazali (2013) uji kolmogrov smirnov merupakan uji normalitas yang umum digunakan karena dinilai lebih sederhana dan tidak menimbulkan perbedaan persepsi, uji ini dilakukan dengan tingkat signifikansi 0,05. Nilai Kolmogrov-Smirnov $<\mathrm{t}_{\text {-tabel}}$, atau menggunakan nilai probability sig $(2$ Tailed $)>(\alpha)=.05$, maka dapat dikatakan normal.

Dalam penelitian ini juga dilakukan pengujian normalitas data, uji normalitas data ini dilakukan sebagai salah satu bagian dari uji persyaratan analisis data atau uji asumsi klasik yang artinya sebelum kita melakukan analisis statistik untuk uji hipotesis dalam hal ini adalah analisis regresi, maka data penelitian pada variabel yang akan dianalisis harus terdistribusi secara normal. Dalam penelitian ini pengujian normalitas data dilakukan dengan uji statistik dengan menggunakan uji kolmogrov smirnov dengan bantuan program spss 23 dengan hasil sebagai berikut:

Tabel 1.2 Uji Normalitas

\begin{tabular}{llr}
\hline \multicolumn{3}{c}{ One-Sample Kolmogorov-Smirnov Test } \\
\hline & & $\begin{array}{c}\text { Unstandardized } \\
\text { Residual }\end{array}$ \\
\hline $\mathrm{N}$ & \multicolumn{1}{c}{ Mean } & 100 \\
\cline { 2 - 3 } Normal Parameters ${ }^{\mathrm{a}, \mathrm{b}}$ & Std. Deviation &, 0000000 \\
\hline Most Extreme Differences & Absolute &, 102 \\
\cline { 2 - 3 } & Positive &, 102 \\
\cline { 2 - 3 } & Negative &,- 051 \\
\hline Kolmogrov-smirnov Z & &, 102 \\
\hline Asymp. Sig. (2-tailed) & &, $013^{\mathrm{c}}$ \\
\hline a. Test distribution is Normal. & & \\
\hline b. Calculated from data. & & \\
\hline c. Lilliefors Significance Correction. & & \\
\hline
\end{tabular}




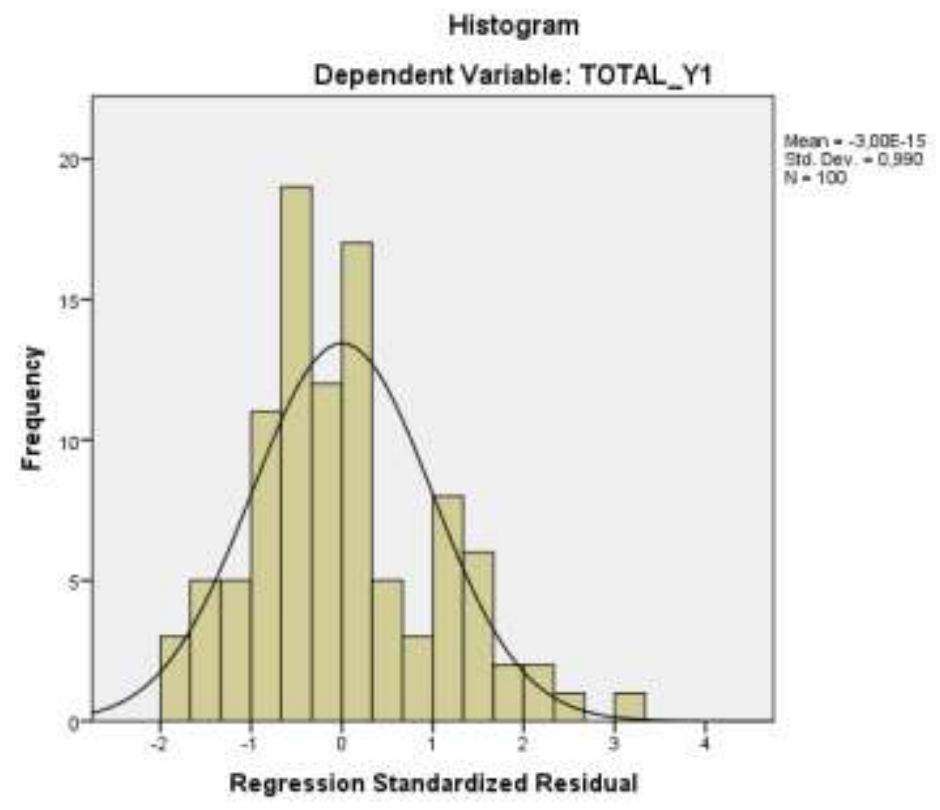

Gambar 1 Histogram Uji Normalitas

Dalam uji normalitas Kolmogrov Smirnov terdapat dasar pengambilan keputusan sebagai berikut:

1. Jika nilai signifikansi (Sig) lebih besar dari 0,05 maka data penelitian terdistribusi normal.

2. Jika nilai signifikansi (Sig.) lebih kecil dari 0,05 maka data penelitian tidak terdistribusi normal.

Berdasarkan dasar pengambilan keputusan di atas maka dapat dilihat tabel hasil uji normalitas yang mendapatkan nilai test statistic kolmogrov smirnov sebesar 0,102 lebih besar dari 0,05. Berdasarkan data tersebut maka data yang digunakan dalam penelitian ini memenuhi persyaratan dan terdistribusi normal.

\section{Uji Multikolinearitas}

Multikolinearitas merupakan suatu situasi dimana beberapa atau semua variabel bebas berkorelasi kuat. Menurut Ghozali (2013) uji multikolinearitas bertujuan untuk menguji apakah model regresi ditemukan adanya korelasi antar variabel bebas (independen). Model regresi yang baik seharusnya tidak terjadi korelasi diantara variabel independen. Jika terdapat korelasi yang kuat diantara semua variabel independen maka konsekuensinya adalah:

a). Koefisien-koefisien regresi menjadi tidak dapat ditaksir 
b). Nilai standar error setiap koefisien regresi menjadi tidak terhingga.

Dengan demikian berarti semakin besar korelasi diantara sesama variabel independen, maka tingkat kesalahan dari koefisien regresi semakin besar yang mengakibatkan standar errornya semakin besar pula. Cara yang digunakan untuk mendeteksi ada tidaknya multikolinearitas adalah dengan menggunakan variance inflation factor (VIF). Metode pengambilan keputusannya jika tolerance lebih dari 0,1 dan VIF kurang dari 10 maka tidak terjadi multikolinearitas.

\section{Uji Heteroskedastisitas}

Menurut Ghozali (2013) model regresi yang baik adalah yang tidak terjadi heteroskedastisitas. Kebanyakan data crossection mengandung situasi heteroskedastisitas karena data ini menghimpun data yang mewakili berbagai ukuran (kecil, sedang, dan besar). Situasi heteroskedastisitas akan menyebabkan penaksiran koefisien-koefisien regresi menjadi tidak efisien dan hasil taksiran dapat menjadi kurang atau melebihi dari yang semestinya. Dengan demikian agar koefisien-koefisien regresi tidak menyesatkan maka situasi heteroskedastisitas tersebut harus dihilangkan dari model regresi. Uji heterokedastisitas merupakan bagian dari uji asumsi klasik dalam model regresi. Salah satu persyaratan yang harus terpenuhi dalam model regresi yang baik adalah tidak terjadi heterokedastisitas. Jika terjadi gejala atau masalah heteroskedastisitas ini akan berakibat pada sebuah keraguan (ketidakakuratan) pada suatu hasil analisis regresi yang dilakukan. Uji heterokedastisitas berfungsi untuk menguji terjadinya perbedaan variance dari nilai residual pada suatu periode pengamatan ke periode pengamatan yang lainnya. Syarat tidak terjadi gejala atau masalah heterokedastisitas jika:

1. Titik-titik data penyebar diatas dan dibawah atau disekitar angka 0

2. Titik-titik tidak mengumpul hanya diatas atau dibawah saja

3. Penyebaran titik-titik data tidak boleh membentuk pola bergelombang melebar kemudian menyempit dan melebar kembali

4. Penyebaran titik-titik tidak berpola. 


\section{Uji Hipotesis}

Setelah melakukan uji normalitas dan uji homogenitas data, untuk melihat pengaruh variabel $(\mathrm{X})$ motivasi diri dan pemberian beasiswa terhadap variabel $(\mathrm{Y})$ pengambilan keputusan pegawai dalam melanjutkan pendidikan ke perguruan tinggi. Maka dapat dilakukan uji hipotesis dengan menggunakan rumus SPSS Independent Samples T-Test. Ada dua tahap yang harus dilakukan dalam pengujian ini.

\section{A. Pengujian Secara Keseluruhan (Simultan) dengan Uji F}

Uji ini dilakukan untuk menunjukkan apakah semua variabel indpenden yang dimasukkan dalam model mempunyai pengaruh secara bersama-sama terhadap variabel dependen. Uji $\mathrm{f}$ dilakukan dengan membandingkan $f$-value (f hitung) yang diperoleh dari hasil regresi dengan $\mathrm{f}$ signifikan (f tabel) yang telah ditetapkan. Kriteria ujinya adalah tolak $\mathrm{H}_{\mathrm{o}}$ jika $\mathrm{f}_{\text {hitung }}>\mathrm{f}_{\text {tabel. }}$.

\section{B. Pengujian Secara parsial dengan Uji t}

Uji ini dilakukan untuk mengetahui apakah variabel independen secara individual mempengaruhi variabel dependen secara parsial. Dengan $\mathrm{df}=\mathrm{n}-1$ dan $\mathrm{t}_{\text {tabel }}=(1-\alpha)$, pada taraf signifikansi $\alpha=5 \%(0,005)$ uji satu pihak kanan. Kriteria $\mathrm{H}_{\mathrm{a}}$ diterima jika $t_{\text {hitung }}>t_{\text {tabel }}$ dan $H_{a}$ ditolak jika $t_{\text {hitung }}<t_{\text {tabel. }}$. Dengan demikian $t_{\text {hitung }}>t_{\text {tabel, }}$, tolak $H_{o}$ dan terima $\mathrm{H}_{\mathrm{a}}$ artinya terdapat pengaruh yang signifikan. Hipotesis yang diajukan adalah:

1. $\mathrm{H}_{\mathrm{a}}$ : Terdapat pengaruh motivasi diri terhadap keputusan pegawai dalam melanjutkan pendidikan ke perguruan tinggi.

$\mathrm{H}_{0} \quad$ : Tidak terdapat pengaruh motivasi diri terhadap keputusan pegawai dalam melanjutkan pendidikan ke perguruan tinggi.

2. $\mathrm{H}_{\mathrm{a}} \quad$ : Terdapat pengaruh pemberian beasiswa terhadap keputusan pegawai dalam melanjutkan pendidikan ke perguruan tinggi.

$\mathrm{H}_{0} \quad$ : Tidak terdapat pemberian beasiswa terhadap keputusan pegawai dalam melanjutkan pendidikan ke perguruan tinggi.

3. $\mathrm{H}_{\mathrm{a}} \quad$ : Terdapat pengaruh dari motivasi diri dan pemberian beasiswa terhadap keputusan pegawai dalam melanjutkan pendidikan ke perguruan tinggi.

$\mathrm{H}_{\mathrm{o}} \quad$ : Tidak terdapat pengaruh dari motivasi diri dan pemberian beasiswa terhadap keputusan pegawai dalam melanjutkan pendidikan ke perguruan tinggi. 


\section{HASIL DAN PEMBAHASAN}

\section{Pengaruh Motivasi Diri Terhadap Pengambilan Keputusan Pegawai Dalam Melanjutkan Pendidikan Ke Perguruan Tinggi}

Berdasarkan ouput yang didapatkan dari penghitungan dengan menggunakan SPSS diketahui nilai t-hitung sebesar 5,558 maka t-hitung yang diperoleh jauh lebih besar dari nilai t-tabel sebesar 1,98742 yang diperoleh dari rumus t tabel $=(\alpha / 2 ; n-k-1)$ dengan signifikansi sebesar $0,000<\alpha(0,05)$. Dengan demikian berdasarkan data-data tersebut dapat disimpulkan bahwa variabel motivasi diri berpengaruh secara positif dan signifikan terhadap pengambilan keputusan pegawai dalam melanjutkan pendidikan. Data hasil analisis secara statistik tersebut sejalan dengan teori yang dikemukakan oleh uno (2016) bahwa kata motivasi berkaitan dengan kata motif, jika motif adalah daya penggerak dalam diri seseorang untuk melakukan aktivitas tertentu demi mencapai tujuan tertentu, dengan demikian motivasi merupakan dorongan yang terdapat dalam diri seseorang untuk berusaha mengadakan perubahan tingkah laku yang lebih baik dalam memenuhi kebutuhannya. Dalam konsep motivasi tercakup konsep-konsep seperti kebutuhan untuk berprestasi, kebutuhan berafiliasi, kebiasaan, dan keingintahuan seseorang terhadap sesuatu. Motivasi dalam hal ini juga termasuk motivasi diri seseorang untuk melanjutkan pendidikan ke perguruan tinggi walaupun dia sudah bekerja di suatu perusahaan. Hal ini didasari karena adanya motivasi diri yang sangat baik dari dalam diri individu untuk mencapai tujuan tertentu hingga akhirnya individu tersebut memutuskan untuk melanjutkan pendidikan misalnya untuk mendapatkan gelar, meningkatkan status sosial dalam masyarakat, untuk meningkatkan karir pada saat bekerja, dan hal-hal lainnya

\section{Pengaruh Pemberian Beasiswa Terhadap Pengambilan Keputusan Pegawai Dalam Melanjutkan Pendidikan Ke Perguruan Tinggi}

Berdasarkan ouput yang didapatkan dari penghitungan dengan menggunakan SPSS diketahui nilai t-hitung sebesar 2,281 maka t-hitung yang diperoleh jauh lebih besar dari nilai t-tabel sebesar 1,98742 yang diperoleh dari rumus t tabel $=(\alpha / 2 ; n-k-1)$ dengan signifikansi sebesar $0,025<\alpha(0,05)$. Dengan demikian berdasarkan data-data tersebut dapat disimpulkan bahwa variabel intensitas pemberian beasiswa berpengaruh secara positif dan cukup signifikan dalam pengambilan keputusan pegawai dalam melanjutkan pendidikan. Data hasil analisis statistik tersebut sejalan dengan pendapat 
Murniasih (2009) bahwa beasiswa diartikan sebagai bentuk penghargaan yang diberikan kepada individu agar dapat melanjutkan pendidikan ke jenjang yang lebih tinggi. Penghargaan itu dapat berupa akses tertentu pada suatu institusi atau penghargaan berupa bantuan keuangan. Bantuan pendidikan seperti beasiswa ini diberikan kepada seseorang atas dasar prestasi yang diraih atau karena kemampuan ekonomi yang belum memadai. Beasiswa dapat diberikan oleh pemerintah, perusahaan ataupun yayasan. Beasiswa dapat dikategorikan pada pemberian cuma-cuma ataupun pemberian dengan ikatan kerja (biasa disebut ikatan dinas) setelah selesainya pendidikan. Beasiswa ini menjadi salah satu faktor yang mempengaruhi pengambilan keputusan pegawai dalam melanjutkan pendidikan ke jenjang perguruan tinggi.

\section{Analisis Koefisien Determinasi}

Analisis koefisien determinasi menggunakan metode analisis $R$ Square untuk melihat kuat-lemahnya model analisis secara keseluruhan antara 2 variabel bebas (variabel motivasi diri dan intensitas pemberian beasiswa) dengan variabel terikat (pengambilan keputusan pegawai).

Tabel 1.3 R square

\begin{tabular}{|c|c|c|c|c|c|c|c|c|c|}
\hline \multirow[b]{2}{*}{$\begin{array}{c}\text { Mod } \\
\text { el }\end{array}$} & \multirow[b]{2}{*}{$\mathrm{R}$} & \multirow[b]{2}{*}{$\begin{array}{c}\mathrm{R} \\
\text { Square }\end{array}$} & \multirow[b]{2}{*}{$\begin{array}{l}\text { Adjusted } \\
\text { R Square }\end{array}$} & \multirow{2}{*}{$\begin{array}{c}\text { Std. Error } \\
\text { of the } \\
\text { Estimate }\end{array}$} & \multicolumn{5}{|c|}{ Change Statistics } \\
\hline & & & & & $\begin{array}{c}\text { R Square } \\
\text { Change }\end{array}$ & $\begin{array}{c}\text { F } \\
\text { Change }\end{array}$ & df1 & $\mathrm{df} 2$ & $\begin{array}{c}\text { Sig. F } \\
\text { Change }\end{array}$ \\
\hline 1 &, $650^{\mathrm{a}}$ & ,422 & ,410 & 5,28202 & ,422 & 35,407 & 2 & 97 & ,000 \\
\hline
\end{tabular}

Berikut adalah penjelasan secara garis besar data-data dalam tabel model summary diatas yang penghitungannya dilakukan dengan menggunakan bantuan SPSS 23. Kolom model menunjukkan jumlah model analisis yang dibentuk dalam penelitian ini adalah 1. kolom $R$ menunjukkan seberapa baik variabel-variabel bebas memprediksi hasil. Kisaran nilai $R$ adalah 0 hingga 1 semakin nilai $R$ mendekati angka 1 maka akan semakin kuat variabel-variabel kuat bebas memprediksi variabel terikat. Namun ketetapan nilai $R$ ini lebih disempurnakan dengan kolom Rsquare yang ada disebelahnya yang merupakan korelasi atas nilai $R$. Dalam penelitian ini nilai $R$ (korelasi antar variabel penelitian) sebesar 0.650 dan $R$ Square sebesar 0,422, menunjukkan bahwa variabel motivasi diri dan pemberian beasiswa mampu menjelaskan variabel pengambilan keputusan pegawai sebesar 42,2\% dengan kata lain 42,2 \% pengambilan keputusan pegawai ditentukan oleh motivasi diri pegawai dan 
pemberian beasiswa yang diberikan oleh pegawai, sedangkan selebihnya sebesar $57,8 \%$ dipengaruhi oleh faktor lain yang tidak diteliti dalam penelitian ini.

\section{Pengaruh Motivasi Diri dan Pemberian Beasiswa Terhadap Pengambilan Keputusan Pegawai Dalam Melanjutkan Pendidikan Ke Perguruan Tinggi}

Berdasarkan hasil penelitian menunjukkan bahwa motivasi diri dan pemberian beasiswa secara bersama-sama memiliki pengaruh yang signifikan terhadap pengambilan keputusan pegawai dalam melanjutkan pendidikan ke perguruan tinggi $\mathrm{d}$ di PT Kereta Api Indonesia Divisi Regional III Palembang. Hasil uji F menunjukkan bahwa nilai $\mathbf{F}$ hitung 35,407 $>$ F tabel 3.09 atau Sig. 0,000 $<\alpha(0,05)$ maka Ho ditolak artinya ada pengaruh yang positif antara motivasi diri dan intensitas pemberian beasiswa terhadap pengambilan keputusan pegawai dalam melanjutkan pendidikan ke perguruan tinggi. Hal ini berarti semakin tinggi motivasi diri dan pemberian beasiswa maka semakin tinggi pengambilan keputusan pegawai dalam melanjutkan pendidikan ke perguruan tinggi.

Setelah dilakukan uji F berdasarkan penghitungan nilai $R$ Square yang diperoleh dari penghitungan analisis koefisien determinasi diperoleh hasil dalam penelitian ini nilai $R$ sebesar 0.650 (korelasi antar variabel) dan $R$ Square sebesar 0,422, menunjukkan bahwa variabel motivasi diri dan pemberian beasiswa mampu menjelaskan variabel pengambilan keputusan pegawai sebesar 42,2 \% dengan kata lain 42,2 \% pengambilan keputusan pegawai ditentukan oleh motivasi diri pegawai dan pemberian beasiswa yang diberikan oleh perusahaan sedangkan selebihnya sebesar 57,8 \% dipengaruhi oleh faktor lain yang tidak diteliti dalam penelitian ini misalnya faktor beban kerja, faktor lingkungan kerja, faktor keadaan sosial dan ekonomi pegawai dan faktor budaya perusahaan itu sendiri. Besarnya pengaruh variabel motivasi diri dan variabel pemberian beasiswa dalam penelitian ini tidak sama besarnya. Pengaruh variabel motivasi diri lebih besar nilainya dibandingkan dengan variabel intensitas pemberian beasiswa. Perbedaan tersebut dapat dilihat dari nilai B sebesar 0,511 atau $51 \%$ untuk variabel motivasi diri dan sebesar 0,210 atau $21 \%$ untuk variabel pemberian beasiswa.

Berdasarkan hasil tersebut didapatkan kesimpulan bahwa variabel motivasi diri dan variabel pemberian beasiswa berpengaruh baik secara parsial maupun secara simultan terhadap variabel pengambilan keputusan pegawai dalam melanjutkan pendidikan ke perguruan tinggi di PT Kereta Api Indonesia Divisi Regional III 
Palembang. Walaupun variabel motivasi diri dan pemberian beasiswa tersebut memberikan pengaruh secara positif dan signifikan terhadap variabel pengambilan keputusan pegawai namun nilai yang diberikan kedua variabel tersebut menunjukkan hasil yang berbeda terhadap variabel Y. Variabel motivasi diri menunjukkan pengaruhnya dengan nilai yang lebih besar dibandingkan dengan variabel pemberian beasiswa terhadap variabel pengambilan keputusan. Berdasarkan penghitungan sumbangan efektif (SE) variabel motivasi diri menunjukkan nilai sebesar 32\% terhadap variabel pengambilan keputusan dan variabel intensitas pemberian beasiswa menunjukkan nilai sebesar 10,2 \% terhadap variabel pengambilan keputusan pegawai. Dengan demikian dapat disimpulkan bahwa variabel X1 memiliki pengaruh lebih dominan terhadap variabel Y daripada variabel X2. Untuk total SE adalah sebesar 42,2 $\%$ atau sama dengan koefisien determinasi analisis regresi sebesar 42,2 \%.

Dari penghitungan analisis statistik yang diperoleh dengan bantuan program spss tersebut dapat disimpulkan bahwa motivasi diri menunjukkan pengaruh yang lebih besar terhadap pengambilan keputusan pegawai untuk melanjutkan pendidikan ke jenjang perguruan tinggi. Dalam hal ini dapat diartikan bahwa keputusan pegawai untuk melanjutkan pendidikan ke perguruan tinggi adalah didasarkan motivasi diri yang besar timbul dari dalam diri pegawai tersebut. Menurut Uno (2016) motivasi terbagi menjadi dua yaitu motivasi intrinsik dan ekstrinsik. Motivasi intrinsik adalah motivasi yang berasal dari diri seseorang itu sendiri tanpa dirangsang dari luar. Motivasi intrinsik juga diartikan sebgai motivasi yang mendorongnya ada kaitan langsung dengan nilai-nilai yang terkandung di dalam tujuan pekerjaan sendiri. Keinginan yang datang dari dalam diri dilatarbelakangi oleh pemikiran yang positif bahwa semua yang dipelajari saat ini akan dibutuhkan dan sangat berguna dimasa mendatang sedangkan motivasi ekstrinsik adalah motivasi yang datang karena adanya rangsangan dari luar. Motivasi ini disebabkan faktor pendorong lain yang tidak ada hubungannya dengan nilai yang terkandung dalam tujuan pekerjaannya. Motivasi ekstrinsik seseorang untuk melanjutkan pendidikan ke perguruan tinggi misalnya adanya dorongan dari keluarga dan dorongan dari teman.

Dari faktor motivasi diri itulah kemudian timbul faktor lain yang juga dapat mempengaruhi pegawai untuk melanjutkan pendidikan ke jenjang perguruan tinggi yaitu faktor pemberian beasiswa yang diberikan oleh perusahaan tentu akan menambah 
motivasi diri pegawai untuk melanjutkan pendidikan. Namun dalam penelitian ini besarnya nilai intensitas pemberian beasiswa terhadap pengambilan keputusan pegawai untuk melanjutkan pendidikan ke perguruan tinggi memiliki nilai yang rendah sebesar (10,2 \%) dibandingkan dengan nilai motivasi diri. Dalam penelitian ini di PT Kereta Api Indonesia sendiri menyediakan beasiswa untuk pegawai yang ingin melanjutkan pendidikan namun untuk setiap pegawai yang ingin mendapatkan beasiswa, pegawai tersebut harus mengikuti serangkaian tes dari perusahaan sebagai syarat untuk mendapatkan beasiswa. Pegawai yang sudah memenuhi syarat dan lulus dalam tes tersebut yang akan mendapatkan beasiswa untuk melanjutkan pendidikan.

Berdasarkan hasil statistik sumbangan efekif yang didapat, pemberian beasiswa menunjukkan nilai 10,2\%, nilai ini lebih kecil dibandingkan dengan variabel motivasi diri yang menunjukkan nilai $32 \%$ ke variabel pengambilan keputusan. Hal ini membuktikan bahwa pegawai PT Kereta Api Indonesia tidak terlalu bergantung pada pemberian beasiswa yang diberikan oleh perusahaan dikarenakan adanya serangkaian tes yang diberikan oleh perusahaan sebelum mendapatkan beasiswa dan mungkin masih rendahnya pemberian beasiswa yang didapatkan oleh para pegawai. Rendahnya nilai pemberian beasiswa terhadap pengambilan keputusan pegawai juga menunjukkan bahwa kurangnya pemberian beasiswa yang diberikan oleh perusahaan kepada pegawai yang ingin melanjutkan pendidikan, adalah wajar bila motivasi diri memberi pengaruh lebih besar daripada pemberian beasiswa. Jadi untuk pegawai yang tetap melanjutkan pendidikan walaupun kurangnya pemberian beasiswa terhadap pegawai ataupun pemberian beasiswa yang diberikan oleh perusahaan namun harus melalui serangkaian tes terlebih dahulu, berarti motivasi diri pegawai tersebut sangatlah besar karena didorong dengan keinginan untuk mencapai tujuan sampai berhasil baik dalam pekerjaan dan pendidikan.

\section{KESIMPULAN}

Berdasarkan temuan dan hasil pembahasan maka dapat ditarik kesimpulan pengaruh motivasi diri dan pemberian beasiswa terhadap pengambilan keputusan pegawai dalam melanjutkan pendidikan ke jenjang perguruan tinggi yaitu:

Motivasi diri berpengaruh terhadap pengambilan keputusan pegawai dalam melanjutkan pendidikan ke perguruan tinggi di PT Kereta Api Indonesia Divisi 
Regional III Palembang. Hal ini ditunjukkan dalam hasil Uji t diperoleh hasil t hitung sebesar 5,558 $>\mathbf{t}$ tabel 1,987 dengan signifikansi sebesar $0.000<\alpha(0,05)$. Dengan demikian berdasarkan data-data tersebut dapat disimpulkan bahwa variabel motivasi diri berpengaruh signifikan terhadap pengambilan keputusan pegawai dalam melanjutkan pendidikan ke perguruan tinggi. Hasil penghitungan sumbangan efektif (SE) variabel motivasi diri terhadap pengambilan keputusan pegawai menunjukkan hasil $32 \%$ hal ini menjelaskan bahwa pengambilan keputusan pegawai ditentukan oleh faktor motivasi diri sebesar 32\%. Dari data statistik di atas dapat disimpulkan bahwa variabel $X_{1}$ memberikan pengaruh yang signifikan terhadap variabel $\mathrm{Y}$ jadi semakin kuat motivasi seseorang maka semakin kuat juga keinginan individu tersebut untuk melanjutkan pendidikan ke perguruan tinggi.

Pemberian beasiswa berpengaruh terhadap pengambilan keputusan pegawai di PT Kereta Api Indonesia Divisi Regional III Palembang. Hal ini ditunjukkan dalam hasil uji t diperoleh hasil t hitung sebesar 2,281 > 1,987 dengan signifikansi sebesar $0,025<\alpha(0,05)$. Dengan demikian berdasarkan data-data tersebut dapat disimpulkan bahwa variabel pemberian beasiswa berpengaruh signifikan terhadap pengambilan keputusan pegawai dalam melanjutkan pendidikan. Hasil penghitungan sumbangan efektif (SE) variabel pemberian beasiswa terhadap pengambilan keputusan pegawai menunjukkan hasil 10,2\%. Dari data statistik di atas besarnya nilai sumbangan efektif yang diperoleh oleh variabel pemberian beasiswa lebih kecil dibandingkan dengan variabel motivasi diri. Variabel pemberian beasiswa dalam penelitian ini hanya memberikan nilai 10,2\% saja terhadap variabel $\mathrm{Y}$ atau variabel pengambilan keputusan pegawai. Hal ini bisa disebabkan karena adanya syarat yang diajukan oleh perusahaan bahwa setiap pegawai yang ingin mendapatkan beasiswa harus mengikuti serangkaian tes terlebih dahulu. Pegawai yang lulus dalam tes bisa mendapatkan beasiswa sedangkan yang tidak lulus berarti harus melanjutkan pendidikan tanpa menggunakan beasiswa yang diberikan oleh perusahaan dan hanya didasari oleh motivasi dan keinginan yang kuat.

Variabel motivasi diri dan pemberian beasiswa secara bersama-sama (parsial) berpengaruh terhadap pengambilan keputusan pegawai dalam melanjutkan pendidikan ke jenjang perguruan tinggi. Hal ini didukung dengan hasil penghitungan analisis statistik uji $\mathbf{f}$ dari penghitungan analisis koefisien determinasi diperoleh nilai $\mathbf{f}$ hitung 
sebesar 35,407 $>$ f tabel 3,09 dengan signifikansi 0,000< $\alpha(0,05)$. Dengan demikian berdasarkan data-data tersebut menunjukkan adanya pengaruh yang signifikan antara variabel motivasi diri dan pemberian beasiswa terhadap pengambilan keputusan pegawai. Data hasil analisis koefisien determinasi menghasilkan nilai $R$ Square sebesar 0.422 menunjukkan bahwa variabel motivasi diri dan intensitas pemberian beasiswa mampu menjelaskan variabel pengambilan keputusan pegawai sebesar 42,2 \%. dengan kata lain 42,2 \% pengambilan keputusan pegawai ditentukan oleh motivasi diri dan pemberian beasiswa yang diberikan oleh perusahaan sedangkan selebihnya sebesar 57,8 $\%$ dipengaruhi oleh faktor lain yang tidak dibahas dalam penelitian ini. Faktor-faktor lain yang bisa mempengaruhi pengambilan keputusan dalam penelitian ini misalnya faktor beban kerja, faktor keadaan sosial dan ekonomi pegawai, faktor lingkungan pekerjaan dan faktor budaya perusahaan.

\section{DAFTAR PUSTAKA}

Ghozali, Imam. 2013. Aplikasi Analisis Multivariate Dengan Program SPSS. Edisi Ketujuh, Semarang: Badan Penerbit Universitas Diponegoro.

Idi, Abdullah dan Safarina. 2011. Sosiologi Pendidikan. Jakarta: Rajawali Pers

Wiyani, Novan Ardi.(2013).Desain Pembelajaran Pendidikan. Yogyakarta: Ar-ruz Media.

Martono, Nanang. 2012. Sosiologi Perubahan Sosial:Perspektif Klasik, Modern, Posmodern dan Poskolonial. Jakarta:Rajawali Pers.

Uno, H. B. (2016). Teori Motivasi dan Pengukurannya. Jakarta : Bumi Aksara. 